\title{
Hvordan skabes et alternativ? Om det radikale demokratis mulighedsbetingelser
}

Jannick Schou, ph.d.-stipendiat, Institut for Business IT, IT-Universitetet i København

Den belgiske politiske filosof Chantal Mouffe har over flere årtier udarbejdet en model for såkaldt radikalt demokrati. Hendes demokratiske model lægger vægt på konflikt, affekt og konstruktionen af kollektive identiteter som bærende elementer $\mathrm{i}$ et levende demokrati, og fungerer derved som et korrektiv til den eksisterende neoliberale orden. I denne artikel foretages en kritisk læsning af denne model ved at trække på begreber hentet fra den argentinske filosof Ernesto Laclaus del af diskursteorien. Derigennem problematiseres de underliggende mulighedsbetingelser som Mouffe baserer sin model på, hvilket fremadrettet kan danne grobund for yderligere radikaliseringer af det radikale demokrati.

\section{Introduktion}

Er der et alternativ til det nuværende neoliberale demokrati? Kan demokratiet styrkes, gøres mere inkluderende og mindre teknokratisk? Disse spørgsmål har til stadighed udgjort nogle af de grundlæggende problemkomplekser inden for politisk filosofi. Særligt venstrefløjen har tematiseret disse som et led i en kritik af det kapitalistiske system, blandt andet i form af Jürgen Habermas' (2009 [1962]) model for deliberativt demokrati samt Chantal Mouffes (2005; 2013) post-Marxistiske model for radikalt demokrati (Khan 2013; Karppinen, Moe og Svensson 2008; Kapoor 2002). Denne artikel foretager en analyse og diskussion af den sidstnævnte teori, nemlig Mouffes 'radikale og pluralistiske demokrati', også kaldet agonistisk pluralisme. Ved at trække på centrale begreber fra den argentinske filosof (og Mouffes mangeårige partner) Ernesto Laclau (1990; 1996) vil jeg foretage en teoretisk problematisering af det radikale demokratis mulighedsbetingelser. Mens Mouffes teoridannelse gradvist har vundet forskningsmæssigt indpas over de sidste tyve år (Tambakaki 2010; Dahlberg og Siapera 2007), har der ofte manglet en mere teoretisk diskussion af disse mulighedsbetingelser. Forskningen har alt for ofte ledt efter empiriske manifestationer af radikalt demokrati, i stedet for at spørge ind til Mouffes teoretiske og politiske fundament. Dette er problematisk af flere grunde. Først og fremmest fordi Mouffes eget værk netop tager udgangspunkt i en teoretisk dia- 
$\log$ og dekonstruktion af andre modeller for demokrati. For det andet fordi realiseringen af et radikalt demokrati nødvendigvis må bygge på en refleksion over dets aktualiseringsmuligheder. Hvordan kan et alternativ skabes? Hvad er betingelserne for dette?

Ved at anvende diskursteorien på Mouffe selv bliver det delvist muligt at komme disse problemer i møde. Mouffe er af både biografiske og værkmæssige årsager tæt forbundet med Laclau. Udover at være gift var de også begge forfattere til bogen Hegemony and Socialist Strategy fra 1985. Dette værk har sidenhen dannet grundlaget for ikke blot idéen om radikalt demokrati, men også post-Marxistisk diskursteori i bredere forstand (Howarth 2000; Smith 1998; Torfing 1999). Formålet med denne artikel er dog ikke at overføre Laclaus argumenter eller politiske ontologi til Mouffe. Ej heller at foretage en systematisk sammenligning af disse forfatterskaber (se eksempelvis Wenman 2003). Tilgangen består derimod i at bruge Laclaus koncepter som en form for sensibiliseringsværktøj, der kan hjælpe til at udbygge og viderearbejde Mouffes model. Det er et kritisk konstruktivt snarere end evaluerende eller dekonstruerende projekt, denne artikel er ude i. Jeg vil sætte fokus på de grundlæggende forudsætninger, som Mouffe lægger til grund for sin model, og herigennem spørge, om hendes teoretisering går langt nok.

Artiklens argument er, at det radikale demokrati beror på to mulighedsbetingelser: (1) en fælles konfliktuel konsensus om 'liberty' og 'equality' som tomme universalier, samt (2) en fælles tillid til demokratiets bærende institutioner. I denne artikel vil jeg forsøge at vise, hvordan disse to betingelser dog også fremstår delvist uafklarede i Mouffes forfatterskab. Artiklens argument er således, at Mouffe har en tendens til at underkende disse betingelsers indbyggede politiske implikationer. Hverken Mouffes tomme universalier eller demokratiets eksisterende institutioner er neutrale størrelser. De er derimod - formuleret med Laclaus diskursteoriske begreber - udtryk for sedimenterede og delvist neutraliserede diskurser. Som sådan må de betragtes som dybt politiske størrelser med deres egen indbyggede historik og eget normative grundlag. Mouffe overser eller afskriver for mig at se alt for ofte disse strukturelle betingelser. På denne måde risikerer radikalt demokrati at blive en affirmativ model, der ikke så meget indvarsler en transformation af de nuværende diskurser som deres reproduktion. Artiklens argument er, at Laclaus værk tillader os at se disse uklarheder og derved arbejde mod en fremadrettet radikalisering af det radikale demokrati. Artiklen bidrager til den voksende forskning om alternativ politisk deltagelse (Dahlberg og Siapera 2007; Howarth, Norval og Stavrakakis 2000; Norval 2007; Smith 1998; Husted 2015) og diskursteorien som politisk filosofi (Marchart 2007; Critchley og Marchart 2004; Schou 2016; Dahlberg 2014). Ved at undersøge det radikale demokratis mulighedsbetingelser giver artiklen en større klarhed over, hvad Mouffes model indeholder og ekskluderer. Det bliver derved muligt at viderebygge og radikalisere hendes politiske projekt fremadrettet.

Radikalt demokrati som politisk projekt 
Mouffes model for demokrati blev for alvor lanceret i 1985 med Hegemony and Socialist Strategy skrevet i fællesskab med Laclau. På dette tidspunkt blev betegnelsen radikalt demokrati ('radical democracy') brugt til at rammesætte hendes projekt. I en række senere publikationer, såsom The Return of the Political (1993), The Democratic Paradox (2005a [2000]), On the Political (2005b) og Agonistics (2013) er det dog navnlig betegnelserne 'agonistic pluralism' eller en 'agonistic model of democracy', der bliver anvendt. På trods af disse semantiske forskydninger er grundidéen dog forblevet relativt stabil over tid. Der er ifølge Mouffe tale om et korrektiv til den 'liberale tradition' (personificeret ved Habermas og Rawls), en intervention i den neoliberale orden (Mouffe 2005) og et forsøg på at bryde med de stadigt mere deterministiske modeller, som den Marxistiske tradition tog udgangspunkt i mod slutningen af 1960'erne og 1970'erne. I modsætning til den ortodokse Marxistiske opfattelse af social transformation - der ser dette som et udtryk for et tiltagende antagonistisk forhold mellem forskellige klasser tager Mouffe udgangspunkt i en radikalisering og udbygning af det eksisterende demokrati. Overgangen til et mere inkluderende demokrati sker ikke automatisk, og det kræver ikke en fuldstændig omvæltning af samfundets strukturer. Hvorfor der specifikt er tale om et opgør med neoliberalismen, vil jeg vende tilbage til senere. Først vil jeg dog gennemgå hovedtrækkene i Mouffes teori.

Grundlaget for Mouffes arbejde er en udvidet forståelse af det politiske. Hun indfører derfor en sondring mellem 'politics' og 'the political'. I denne distinktion refererer 'politics' til den helhed af diskurser, praksisser og institutioner, der til daglig forbindes med det institutionaliserede politiske system: "the ensemble of practices, discourses and institutions, which seek to establish a certain order and organize human coexistence" (Mouffe 2005, 101). Over for dette defineres 'the political' som et ontologisk grundvilkår: "By 'the political' I refer to the dimension of antagonism that is inherent in human relations" (Mouffe 2005, 101). Mens 'politics' altså udgør et regionalt fænomen - en afgrænset historisk helhed af institutioner og praksisformer - er 'the political' et kvasi-transcendent vilkår. Der er indbygget et vist antagonistisk konfliktpotentiale $i$ alle menneskelige relationer og $i$ al konstruktion af mening.

Mouffe opfatter grundlæggende demokratiet som et kollektivt anliggende, der handler om at skabe fælles former for identifikation. Demokratiet kan ikke reduceres til et rent individuelt projekt eller en aggregering af individuelle interesser: "democratic logics always entail drawing a frontier between 'us' and 'them', those who belong to the 'demos' and those who are outside it. This is the condition for the very exercise of democratic rights" (Mouffe 2005, 4). Dette argument bygger dels på Carl Schmitts (2007 [1932]) forståelse af det politiske som en grænsedragning mellem et 'os' (ven) og et 'dem' (fjende). Men det tager samtidig også sit udgangspunkt i Jacques Derrida og dekonstruktionen. Hvis konstruktionen af en identitet altid er defineret ud fra dens relation til noget uden for denne, vil der altid være et "konstituerende ydre" (Mouffe 2013, 4-6). At skabe kollektive identiteter indebærer derfor nødvendigvis et forhold mellem et indre ('vi') og et ydre ('dem'). Både det indre og det ydre kan kun eksistere i kraft af deres relation til hinanden. Derfor begår den liberale tradition ifølge Mouffe en fejl, når den 
reducerer demokratiet til individet som en autonom størrelse, eller blot summerer individuelle interesser. Det kollektive kan ikke reduceres til en aggregering af enheder: det er derimod en relation og en grænsedragning.

Demokrati er samtidig grundlæggende konfliktfyldt for Mouffe. Der er aldrig blot tale om en teknisk afvejning af fordele og ulemper ved en given politisk problemstilling. Derimod er politiske spørgsmål udtryk for et valg imellem forskellige, internt modstridende forestillinger om det politiske fællesskab: "Proper political questions always involve decisions that require making a choice between conflicting alternatives" (Mouffe 2013, 3). For Mouffe er det netop dette konfliktpotentiale, som den liberale tænkning ikke kan indeholde og derved prøver at undertrykke. Ifølge den handler politisk praksis om at nå konsensus og enighed ud fra fastlagte procedurer. Derved bliver konflikt afmonteret og ekskluderet fra starten.

Den liberale tradition har samtidig også undertrykt følelser, affekt og passion som legitime og nødvendige dele af demokratiet. Ifølge Mouffe tager hverken Habermas eller Rawls højde for disse elementer i deres teoridannelse. Hvis der skal bygges en ny model for demokratiet - en måde, der kan gøre den demokratiske dialog dybere, øge deltagelse og mindske undertrykkelsen af forskelle - er det derfor nødvendigt at indarbejde affekt som et grundlæggende vilkår i demokratisk deltagelse. Konflikter mobiliserer affekt, og et levende demokrati har brug for mobiliseringen af det affektive. Ellers er der ifølge Mouffe en risiko for, at det ender i en ren teknokratisk situation, hvor folket får en apatisk holdning til det politiske system.

Spørgsmålet er nu, ud fra disse kritikpunkter af alle de elementer der traditionelt set ikke kan indeholdes i demokratiet, hvordan der kan etableres en model, der på en og samme tid tager hensyn til antagonisme og konflikt fremfor konsensus og orden, affekt og passioner fremfor rendyrket fornuft samt pluralisme og kollektivisme fremfor aggregeret individualisme. Det er ifølge Mouffe klart, at eksempelvis Habermas' procedurale forståelse af deliberativt demokrati ikke kan indeholde disse elementer. Så hvordan kan disse genindscettes som ikke blot supplementære dele af demokratiet, men derimod som en del af dets grundlæggende konstitution? Det, der særligt gør dette spørgsmål vanskeligt, er forholdet mellem det antagonistiske og det pluralistiske: Mens antagonisme 'forenkler' det sociale (se Laclau og Mouffe 2014, 117) ved at splitte det op i lejre, handler pluralisme grundlæggende om at kunne rumme mangfoldighed. Hvordan kan kompleksitet bevares i et system, der som grundvilkår søger at reducere dette?

Mouffes svar er en agonistisk model for demokrati. Ifølge Mouffe anerkender en sådan model først og fremmest, at magt og magtrelationer spiller en afgørende rolle for demokratiet. Det betyder først og fremmest, at eksisterende magtrelationer skal omformes, så subjekter, der historisk set ikke har haft adgang til den offentlige sfære og demokratisk deltagelse, får øget indflydelse (Mouffe 2005, 99). Men magtrelationer skal samtidig ikke ses som noget, der kan afskaffes eller fjernes. Som Mouffe $(2005,22)$ skriver: "To acknowledge the existence of relations of power and the need to transform them, while renouncing the illusion that we could free ourselves completely from power - this is what is specific to the project that we have called 'radical and plural democra- 
cy'." Radikalt demokrati handler dermed ikke om at stoppe eller forhindre magtrelationer, men derimod om at skabe institutionelle rum, hvori konflikt kan indeholdes. Dette leder Mouffe til at skitsere sin model for agonistisk pluralisme på følgende vis:

"the aim of democratic politics is to construct the 'them' in such a way that it is no longer perceived as an enemy to be destroyed, but as an 'adversary', that is, somebody whose ideas we combat but whose right to defend those ideas we do not put into question. (...) An adversary is an enemy, but a legitimate enemy, one with whom we have some common ground because we have a shared adhesion to the ethico-political principles of liberal democracy: liberty and equality." (Mouffe 2013, 102)

Denne 'adversary' er det, der definer agonisme. Mens antagonisme er en kamp mellem fjender, er agonisme en kamp mellem 'adversaries'. Formålet med det radikale demokrati er derfor at omforme antagonisme til agonisme. I stedet for at udrydde konflikt skal den anvendes produktivt som selve motoren for demokratiet. Ved at give plads til agonisme - som et centralt led i demokratiets konstitution - kan Mouffe samtidig også give plads til affekt, passioner og konflikt. Demokratiet bliver et rum, hvor der er mulighed for kontinuerlige kampe, hvis formål er at forhandle eller reproducere bestemte hegemoniske ordner. På denne måde er demokratiet aldrig givet på forhånd, men skabes derimod i agonistiske møder mellem kollektive identiteter, der har et fælles grundlag, men er uenige om udformningen af partikulære politiske spørgsmål. Det er netop disse falles mulighedsbetingelser som jeg undersøger nærmere i det følgende. Hvilke konditioner opstiller Mouffe egentlig for implementeringen af agonisme og radikalt demokrati? Hvad skal der til for at skabe dette alternativ?

\section{Det radikale demokratis mulighedsbetingelser}

Før vi nærmer os disse spørgsmål, bør vi dog først undersøge, hvorfor det netop er det neoliberale, som Mouffe spiller op imod. Er der noget specifikt ved denne "hegemoniske diskurs", der gør den særligt problematisk i forhold til Mouffes politiske projekt? Mouffe går sjældent ind i en reel beskrivelse af, hvad hun egentlig forstår ved neoliberalisme som politisk og økonomisk projekt. I The Democratic Paradox fra 2000 beskrives det neoliberale dog på følgende vis:

"From the political standpoint what guides me is the conviction that the unchallenged hegemony of neo-liberalism represents a threat for democratic institutions. Neo-liberal dogmas about the unviolable [sic] rights of property, the all-encompassing virtues of the market and the dangers of interfering with its logics constitute nowadays the 'com- 
mon sense' in liberal-democratic societies and they are having a profound impact on the left, as many left parties are moving to the right and euphemistically redefining themselves as 'centre-left'." (Mouffe 2000, 6)

Neoliberalisme bliver altså her karakteriseret af Mouffe som værende en form for 'common sense', der sætter markedets logikker og privat ejendomsret over alle andre principper. Der er tale om, hvad særligt den foucauldianske forskning inden for neoliberalisme har kaldt for et normativt system eller en bestemt form for rationalitet (se Brown 2015; Dardot og Laval 2013). Som 'common sense' udvisker neoliberalismen sin egen kontingens, og kommer til at fremstå som om "there is no alternative to the existing order" (Mouffe 2005, 31). Samtidig understreger Mouffe også, at denne orden udgør en trussel mod de demokratiske institutioner. Dette skyldes ifølge Mouffe to grundlæggende træk ved det neoliberale system.

For det første vægter neoliberalismen den liberale tradition over den demokratiske. Ifølge Mouffe $(2013,123)$ har det liberale demokrati historisk set været en forening af to (delvist modsatrettede) traditioner: En liberal, der har lagt vægt på frihed og pluralisme, og en demokratisk, som fokuserer på lighed og folkelig suverænitet. Disse to traditioner har ifølge Mouffe eksisteret i et kontinuerligt modsætningsforhold, hvor særligt frihed og lighed har stået over for hinanden. Det neoliberale hegemoni har dog forskudt denne balance, så den demokratiske tradition i stigende grad er blevet udfaset:

"What has happened under neo-liberal hegemony is that the liberal component has become so dominant that democratic values have been eviscerated. Several previous democratic advances have been dismantled, and under the motto of 'modernization', core democratic values have been dismissed as 'archaic'. (...) [I]t is clear that the situation has drastically worsened under neo-liberal hegemony" (Mouffe 2013, 124).

For det andet er neoliberalismen også en trussel for demokratiet, fordi det implicerer en gradvis neutralisering af politisk konflikt og forskellighed. Det neoliberale hegemoni ekskluderer og delegitimerer politisk opposition: "[ $t$ ]he status quo has become naturalized and made into the way 'things really are" (Mouffe 2000, 5). Der er tale om en "post-political trend [...] [that] deprives democratic citizens of an agonistic debate where they can make their voices heard and choose between real alternatives" (2013, 119). På denne måde går Mouffes kritik altså specifikt på det neoliberale: dels fordi det prioriterer den liberale tradition fremfor den demokratiske, og dels fordi det annullerer politisk konflikt. Agonistisk pluralisme, der netop ser konflikt, affekt og deltagelse som grundsten i et velfungerende demokrati, bliver på denne måde et korrektiv til den neoliberale afmontering og neutralisering af politisk kamp. 
Spørgsmålet er imidlertid: Hvordan kan det eksisterende demokrati transformeres? Hvad er mulighedsbetingelserne for radikalt demokrati? I den ovenstående tekst fremhævede jeg, hvordan Mouffe forstår bevægelsen fra antagonisme til agonisme. Mens den antagonistiske relation er konstrueret rundt om 'den anden' som en fjende, der skal udslettes, drejer den agonistiske sig om at se den anden som en legitim modstander ('the adversary'). Det er en medspiller, der opererer inden for samme demokratiske spilleplade. Denne sidste del er vigtig. Mouffe fremhæver netop, at agonisme kræver visse fælles mulighedsbetingelser: "while in conflict, they [adversaries] see themselves as belonging to the same political association, as sharing a common symbolic space within which the conflict takes place" (2005, 20, min fremhævning). Det betyder, at politisk konflikt altid skal virke inden for "conditions regulated by a set of democratic procedures accepted by the adversaries" $(2005,21)$. Mouffe fremhæver i denne forbindelse særligt to træk, der udgør de grundlæggende mulighedsbetingelser for hendes demokratiske model: "Consensus is needed on the institutions that are constitutive of liberal democracy and on the ethico-political values that should inform political association" $(2013,8)$. Enhver mulighed for realiseringen af det radikale demokrati beror altså på en fælles konsensus om de demokratiske institutioner og en række etisk-politiske værdier.

Disse etisk-politiske værdier bliver andre steder specificeret: "liberty and equality constitute the political principles of a liberal democratic regime and should be at the core of a theory of justice in modern democracy" (Mouffe 1993, 52); "consensus is needed on (...) liberty and equality for all" $(2005,31)$ samt "[a] democratic society requires the allegiance of its citizens to a set of shared ethico-political principles [...] and it cannot allow the coexistence of conflicting principles of legitimacy in the midst" (2005, 122). 'Liberty' og 'equality' skal altså ifølge Mouffe udgøre de etisk-politiske grundværdier for det radikale demokrati. Dette betyder dog ikke nødvendigvis, at deres betydning eller indhold skal være fastlagt på forhånd. Det skal derimod være muligt at mobilisere konfliktfyldte fortolkninger af, hvad disse begreber indeholder. 'Liberty' og 'equality' bliver derved en form for tomme universalier. Konsensus om disse skal være en konfliktuel konsensus. De er således på en gang uden for konflikt og genstanden for konflikt. En fælles forpligtelse til disse to begreber udgør det radikale demokratis første mulighedsbetingelse.

Den anden mulighedsbetingelse omhandler de demokratiske institutioner. Omformningen af det nuværende demokrati sker ikke automatisk. Det kræver aktive handlinger, politisk engagement og udformningen af kollektive identiteter. I denne forbindelse er det for Mouffe centralt, at dette sker igennem de nuværende politiske institutioner. Mouffe udbygger dette i en mere direkte kritik af Michael Hardt og Antonio Negris (2004) forestilling om 'Multituden'. Hun anser deres model for at være en 'tilbagetrækningsstrategi': 'In contrast to this strategy of 'withdrawal', I want to offer a different conception of radical politics envisaged in terms of 'engagement' with institutions, with the aim of bringing about a different hegemony" (Mouffe 2013, 71). Dette engagement leder til en form for reformering igennem institutionerne: 


\begin{abstract}
"The exodus approach denies the possibility of a counter-hegemonic struggle within the institutions that disarticulates the constitutive elements of neo-liberal hegemony. It perceives all institutions as monolithic representatives of the forces to be destroyed, and every attempt to transform them is dismissed as reformist illusion. The strategy advocated is one of 'desertion' and of the creation of new social relations outside the existing institutional framework. What is foreclosed is an immanent critique of institutions, whose objective is to transform them into a terrain for contesting the hegemonic order." (Mouffe 2013, 100)
\end{abstract}

For Mouffe handler det altså om at skabe en immanent kritik gennem institutionerne. Demokratiets parlamentariske institutioner er for hende en grundlæggende præmis for etableringen af agonisme og radikalt demokrati. I et forsøg på at underbygge dette argument skriver Mouffe $(2013,23)$, at det parlamentariske systems sammenbrud i naziTyskland var stærkt medvirkende til, at jøderne blev artikuleret som en antagonistisk 'Anden' der skulle udryddes: "This, I think, is something worth meditating on for leftwing opponents of parliamentary democracy!" Mouffe anser derfor den egentlige kritik af det eksisterende regime som "a call for a radicalization of liberal democratic institutions, not for their rejection" $(2013,119-120)$. Det betyder også, at "the real task (...) is to foster allegiance to our democratic institutions" (Mouffe 1993, 151). Mulighedsbetingelse nummer to er altså en grundlæggende tillid til det demokratiske systems institutioner.

\title{
Ernesto Laclaus politiske ontologi
}

Efter at have redegjort for Mouffes position i det ovenstående vil jeg i dette afsnit vende mig mod Ernesto Laclau. Jeg vil argumentere for, at en række centrale begreber fra den laclauianske del af diskursteorien gør det muligt at udbygge og viderearbejde dele af Mouffes teoridannelse. Udgangspunktet for dette er i første omgang en behandling af Laclaus differentiering mellem 'the political' og 'the social'. Denne distinktion minder til dels om Mouffes, og hendes begrebspar er faktisk til tider blevet anvendt til at beskrive Laclaus værk (herom, se Marchart 2007). I New Reflections on The Revolution of Our Times fra 1990 udfolder Laclau dog forskellen mellem 'the political' og 'the social' på en måde, der fremstår væsentligt forskelligt fra Mouffe.

For Laclau såvel som Mouffe har 'the political' primat. Deres fælles sociale ontologi er derved grundlæggende en politisk ontologi (Laclau og Mouffe 2014; Laclau 1990; Marchart 2007). Men mens 'the political' for Mouffe udgør en altid potentiel antagonisme, der er til stede $i$ alle sociale relationer, peger Laclaus brug i en lidt anden retning. Han beskriver således 'the political' som "[t]he moment of antagonism where 
the undecidable nature of the alternatives and their resolution through power relations becomes fully visible" (Laclau 1990, 35); "the moment of original institution of the social [which] is the point at which its contingency is revealed, since the institution (...) is only possible through the repression of options that were equally open" (Laclau 1990, 34, oprindelig fremhævning) og "the original act of institution" (Laclau 1990, 35). "The political' udgør det øjeblik, hvor en beslutning bliver truffet mellem forskellige mulige valg. I det øjeblik beslutningen bliver truffet, fremstår verden kontingent og principielt set åben. Den kunne være anderledes. Hvis produktionen af mening aldrig kan spores tilbage til 'fast' grund, men derimod er en historisk konstruktion, udgør 'the political' et helt grundlæggende moment i Laclaus politiske ontologi. Det er øjeblikket, hvor bestemte meningssystemer bliver indstiftet. Det politiskes "essens" er ifølge Laclau netop denne indstiftende beslutning, hvor der sondres mellem det inkluderede og det ekskluderede (Laclau 1990, 160).

I hverdagen fremstår verden dog ikke nødvendigvis politisk, åben og kontingent (Laclau 2005, 154). Den er derimod udgjort af mere eller mindre 'objektive' strukturer, der virker neutrale og de-politiserede. For Laclau dækker 'the social' netop over dette: "the sedimented forms of 'objectivity' make up the field of what we will call the 'social"' (Laclau 1990, 35). Sedimentering er et begreb, Laclau henter fra Edmund Husserl, og det dækker over en forglemmelse eller neutralisering af de indstiftende operationer: "the routinization and forgetting of the origins" (Laclau 1990, 34). Bevægelsen fra 'the political' til 'the social' kan ses som en sedimenteringsproces, der får det kontingente til at fremstå naturligt eller nødvendigt. I denne proces glemmes det, at alle strukturer er blevet produceret og konstrueret. På denne måde skjules alle de bagvedliggende magtkampe, der har været impliceret i produktionen af mening over tid.

Laclau understreger vigtigheden af distinktionen mellem 'the political' og 'the social'. Der er ikke blot tale om et historisk eller regionalt fænomen, men om ontologiske grundvilkår, der dækker for al mening og alle sociale relationer: "social relations are constituted by the very distinction between the social and the political. (...) The distinction between the social and the political is thus ontologically constitutive of social relations" (Laclau 1990, 35).

Det er i denne forbindelse vigtigt at påpege forskellen mellem Laclau og Mouffes begrebspar. Selvom deres respektive distinktioner udspringer af en lang række fælles forudsætninger, så betoner de forskellige perspektiver. Hos Laclau er både 'the political' og 'the social' ontologiske størrelser. Verden er på en gang og til alle tider givet $\mathrm{i}$ spændet mellem disse to. Hos Mouffe er antagonismen derimod altid potentiel. Selvom al form for mening er baseret på eksklusion og et 'konstituerende ydre', så er der ikke nødvendigvis tale om en antagonistisk relation. 'The political' bliver for hende en altid potentiel antagonisme i sociale relationer. Laclaus konceptualisering af samme begreb forekommer i denne forbindelse ret anderledes: det er det diskursives (af)grund eller indstiftende øjeblik. I modsætning til Laclaus 'the social' omhandler Mouffes forståelse af 'politics' derudover ikke et ontologisk niveau. Det er derimod en samlebetegnelse for en række bestemte praksisser, diskurser og institutioner. Der kan altså godt være en ver- 
den uden 'politics', men ikke en verden uden 'the social'. Og omvendt kan 'politics' godt være en del af 'the social' (hvilket det på mange måder ofte vil være), men den sidstnævnte betegnelse kan også dække over en lang række andre praksisfelter. Tabel 1 illustrerer disse forskelle. I det følgende vil jeg genbesøge mulighedsbetingelserne for Mouffes model for radikalt demokrati igennem dette laclauianske begrebspar. Den subtile forskydning, der åbner sig imellem Laclau og Mouffes respektive distinktioner, gør det muligt at se det radikale demokratis mulighedsbetingelser fra en anden vinkel.

\begin{tabular}{|c|c|c|}
\hline \multirow{3}{*}{ Mouffe } & The Political & Politics \\
\hline & $\begin{array}{l}\text { Altid potentiel antagonisme } \\
\text { i sociale relationer }\end{array}$ & $\begin{array}{l}\text { Det system af praksisser og } \\
\text { institutioner, der historisk } \\
\text { set er blevet forbundet } \\
\text { med politik }\end{array}$ \\
\hline & Ontologisk & Ontisk \\
\hline \multirow{3}{*}{ Laclau } & The Political & The Social \\
\hline & $\begin{array}{l}\text { Det øjeblik, hvor der son- } \\
\text { dres mellem inde og ude, } \\
\text { inklusion og eksklusion }\end{array}$ & $\begin{array}{l}\text { En neutralisering, forglem- } \\
\text { melse og institutionalise- } \\
\text { ring af 'the political' }\end{array}$ \\
\hline & Ontologisk & Ontologisk \\
\hline
\end{tabular}

Tabel 1: Forskel mellem Mouffe og Laclau

Det radikale demokratis mulighedsbetingelser og deres tærskel

I den ovenstående gennemgang af Mouffes model for radikalt demokrati viste jeg, hvordan hun særligt insisterer på to mulighedsbetingelser. For det første at der til grund for konflikt $i$ et radikalt demokrati skal være konfliktuel konsensus om demokratiets grundlæggende etisk-politiske værdier: 'liberty' og 'equality'. For det andet at transformationen af det neoliberale demokrati bør ske gennem demokratiets eksisterende institutioner. Mouffes kontinuerlige forpligtelse på disse to mulighedsbetingelser kan på mange måder ses som et forsøg på at forene 'the political' og 'politics'. Hvordan kan den altid potentielle antagonisme i sociale relationer håndteres inden for det demokrati- 
ske system på en produktiv måde? Mouffes svar: ved at omforme antagonisme til agonisme ud fra nogle fælles demokratiske mulighedsbetingelser. Spørgsmålet er imidlertid, hvordan disse betingelser tager sig ud, hvis de bliver set igennem Laclaus politiske ontologi.

Som beskrevet i ovenstående udgør 'liberty' og 'equality' en form for 'tomme universalier' hos Mouffe. Ifølge hende bør de danne fælles ramme om det radikale demokrati. Men hvor kommer disse begreber egentlig fra? Og hvorfor er det netop disse og ikke andre, der bør danne fundamentet for radikalt demokrati? Her peger Mouffe på traditionens rolle (Mouffe 1993, 15-18). Traditionen implicerer for Mouffe en historisering af samtidens begreber. Vi er på en gang formet og indsat i historien ifølge Mouffe. På denne måde bliver 'liberty' og 'equality' historiske størrelser, der over tid har konstitueret hjørnestenen i det liberale demokrati. Begreberne kommer altså fra den politiske filosofis historie. Samtidig understreger hun også, at betydningen af disse begreber ikke er fastlåst. Der bør netop være plads til forskellige fortolkninger og forståelser af dette begrebspar. Derfor bliver disse universalier tømt for iboende og essentielt indhold. Men indeholder ikke også den neoliberale diskurs i høj grad en fortolkning af 'liberty' og 'equality'? Selvom Mouffe har en tendens til at argumentere for, at det neoliberale system opsplitter og ødelægger disse to begreber, så er spørgsmålet, om sagen er helt så lige til. Bygger neoliberalismen virkelig på en total afmontering af 'liberty' og 'equality'? Eller er der i højere grad tale om, at Mouffe ikke er enig i dette systems artikulation af disse begreber, og derfor affejer det neoliberale projekt? Med andre ord og mere substantielt: Hvor går grænsen egentlig for, hvad disse begreber kan betyde? Hvis meningen af 'liberty' og 'equality' principielt set er kontingent og åben, så betyder det også at fortolkningen og forståelsen af disse kan variere enormt. Men hvor stor en elasticitet har disse begreber, når det kommer til stykket? Hvor langt kan de trækkes fra 'traditionens' opfattelse af disse, før de ikke længere kan kategoriseres som 'værende' disse betegnere? For mig at se er problemet her, at Mouffe på den ene side understreger elasticiteten i begreberne 'liberty' og 'equality'. Men på den anden side påpeger Mouffe dog netop også traditionen og disse begrebers historik. Disse begreber er altså både uden for det konfliktuelle - idet de skal danne et fælles grundlag - men de er også en del af det konfliktuelle, idet de er åbne for forskellige perspektiver. Som 'tomme universalier' skal begreberne sættes $\mathrm{i}$ en form for historisk parentes. Vi skal glemme deres tradition for derigennem at gøre dem åbne for divergerende fortolkninger. Men grunden til at disse begreber er vigtige, er netop på grund af deres historiske betydning. 'Liberty' og 'equality' er altså på én og samme tid inden for og uden for aksen mellem 'the political' og 'the social': de er indlejret i traditionens sedimenterede strukturer, men konceptualiseres samtidig også, som om de er åbne, kontingente og elastiske.

Mouffes anden mulighedsbetingelse indbefatter de demokratiske institutioners rolle. Som tidligere beskrevet anser Mouffe demokratiets institutioner som en fuldstændig bærende del af hendes projekt. For Mouffe handler det om at omforme det politiske system gennem institutionerne. Hun har dog en ret konsistent tendens til at tilsidesætte disse politiske institutioners normative og sedimenterede strukturer i hendes beskrivel- 
ser af det radikale demokrati. Men hvis vi skal følge Laclaus begrebsbrug, så bør det nuværende demokratis politiske institutioner netop ses som en del af 'the social', idet de er et kerneelement i reproduktionen af det neoliberale demokratis grundlæggende normative strukturer. Institutionerne - og de logikker og praksisser, som de fordrer, - er produktet af bestemte magtkampe, der har fundet sted over tid. De er lige så diskursive som tekst og sprog. Og de indeholder derfor bestemte måder at indrette og forme praksisser, der er gjort 'usynlige', 'neutrale' og 'objektive' over tid. Fælles forpligtelse på de demokratiske institutioner bliver derved også en implicit forpligtelse på de sedimenterede strukturer, som disse udgør.

Mouffe er ikke blind over for dette. I On the Political - hvor hun rent faktisk eksplicit trækker på Laclaus distinktion mellem 'the political' og 'the social' (Mouffe 2005, 17-18) - påpeger hun, hvorledes "society is always politically instituted", hvorfor vi ikke må glemme, at "the terrain in which hegemonic interventions take place is always the outcome of previous hegemonic practices and that it is never a neutral one" (Mouffe 2005, 34). Mouffe er altså langt hen ad vejen enig i, at de politiske institutioner ikke blot er neutrale, men derimod udtryk for bestemte diskurser, der er blevet sedimenteret over tid. På trods af dette har hun en tendens til at identificere det radikale demokrati med, hvad vi kan kalde for politisk praksis i snæver forstand. I sidste ende synes Mouffe nemlig mest interesseret i konfrontationen mellem forskellige forståelser og meningssystemer. Det er den åbne, affektive og konfliktfyldte kamp mellem diskursive projekter, hun lægger vægt på:

"Instead of trying to design the institutions which, through supposedly 'impartial' procedures, would reconcile all conflicting interests and values, the task for democratic theorists and politicians should be to envision the creation of a vibrant 'agonistic' public sphere of contestation where different hegemonic political projects can be confronted. This is, in my view, the sine qua non for an effective exercise of democracy." (Mouffe 2005, 3, oprindelig fremhævning)

Ordet 'exercise' er vigtigt i denne passage: Demokrati er noget der gøres i mødet mellem hegemoniske projekter. Det handler om "the [...] practices of democratic politics" (Mouffe 2005, 9) og såkaldte "democratic 'language-games' " (Mouffe 2005, 33). Institutionerne skal derved omformes gennem "the discourses, the practices, the 'language games' that produce democratic 'subject positions'." (Mouffe 1993, 151). Mouffe er altså ikke blind over for institutionernes rolle, men hendes teoretisering synes alligevel ikke at dække disse. Det er som om, de konstant glider i baggrunden. Hun nævner dem ofte en passant og går herefter videre til at beskrive den demokratiske konfrontation som et sprogspil eller praksis. Men hvordan, kan man spørge, rammesætter bestemte sedimenterede institutioner egentlig mulighederne for politisk praksis? Hvad er forholdet mellem nye former for radikaliserede politiske praksisser og de eksisterende institutionelle rammer? Er det eksempelvis muligt at forestille sig nye måder at skabe politisk 
konfrontation, uden at de politiske institutioner ændres? Og endnu mere substantielt: Nødvendiggør det radikale demokrati et opgør med den neoliberale orden, eller er Mouffes model mulig inden for dette systems eksisterende institutionelle rammer? For mig at se anderkender Mouffe således, hvordan institutionerne indgår som en del af 'the social'. Men samtidig har hun dog også en tendens til at afskrive betydningen af dette i hendes konkrete beskrivelser af politisk praksis. Ved at gøre f.eks. Hardt og Negri til repræsentanter for en tilbagetrækningsstrategi - der ser på hele det institutionelle apparat som et monolitisk og uforanderligt maskineri - er Mouffe også med til at undgå disse mere komplicerede spørgsmål. Er der vitterligt ikke en tredje vej imellem fuldstændig tilbagetrækning og institutionel neutralisering?

\section{Konklusion: Hvordan skabes et alternativ?}

Denne artikel har forsøgt at foretage en relativt afgrænset manøvre. Den har problematiseret mulighedsbetingelserne for den politiske filosof Chantal Mouffes model for radikalt demokrati igennem begreber lånt fra Ernesto Laclaus del af diskursteorien. Selvom deres individuelle forfatterskaber udspringer af en række fælles forudsætninger og argumenter, så har de alligevel udviklet sig i forskellige retninger. Gennem en relativt fintmasket gennemgang af Mouffes model for radikalt demokrati har jeg vist og diskuteret de mulighedsbetingelser, der ligger til grund for hendes politiske projekt. Jeg har derudover demonstreret, hvordan Laclaus distinktion mellem 'the political' og 'the social' kan virke som en løftestang til en problematisering af disse betingelser. Så hvad er denne artikels implikationer?

Først og fremmest peger den på en grundlæggende spænding, der både kan findes hos Mouffe og Laclau: nemlig forholdet mellem anti-essentialisme og normativitet. På den ene side betoner de begge, hvorledes mening aldrig kan forankres i en fast og ahistorisk grund, men derimod altid er produktet af historiske interventioner og forsøg på at etablere hegemoniske projekter. Der er altså tale om en kritik af universalier og tilsyneladende objektive diskurser. Men samtidig holder de også fast i, at venstrefløjen skal og bør være i stand til at udarbejde nye normative politiske projekter. Problemet ved dette er, at sådanne normative projekter netop har brug for fast grund under fødderne. Forestillingen om 'traditionen' som Mouffe trækker på - og som i øvrigt også kan findes hos Laclau (1990) - udgør et forsøg på at koble det anti-essentialistiske og det normative. Men det kræver også en yderligere eksplicitering. Hvornår kan venstrefløjen ikke længere stå inde for den måde, hvorpå traditionen approprieres af eksempelvis neoliberale kræfter? Hvor går grænsen for, hvad traditionens begreber kan indeholde? Og hvem trækker disse grænser? Selvom vi ikke skal lade os fange i absolutte krav om eksempelvis Fornuft som eneste legitime princip (se Howarth 2000), så er traditionens rolle stadig ambivalent i Mouffes politiske projekt. Er venstrefløjen og den liberale traditions grundlæggende værdier overhovedet så sammenfaldende, som de ofte fremstår hos Mouffe? 
Dernæst så peger artiklen på en spænding mellem institutionel forandring og konservering. Dette forhold er ikke kun aktuelt i forhold til en rent intern læsning af Mouffes værk. Spørgsmålet går derimod igen i store dele af den kritiske venstrefløjs politiske filosofi. Er det muligt at bevare grundinstitutionerne i det eksisterende demokrati og samtidig forandre måden, hvorpå det praktiseres? Kan disse aspekter overhovedet skilles ad? Den slovenske filosof Slavoj Žižek (2000a, b) har af flere omgange kritiseret Mouffe (og Laclau) for at glemme den egentlige kritik af det kapitalistiske system og økonomien. Ved at fokusere på politiske forskelle og diskursive kampe neutraliseres kritikken af den politiske økonomi ifølge Žižek. Demokratisk konflikt og deliberation er sådan set fint, men hvordan er dette med til at forandre institutionelt forankrede forhold i den politiske økonomi? Andre forfattere på venstrefløjen, såsom Dardot og Laval (2013), har også kritiseret forestillinger om 'participatory' og radikalt demokrati for simpelthen ikke at gå langt nok i opgøret med det neoliberale systems hegemoni. Et forsvar for det liberale demokrati kan ikke være venstrefløjens sidste bastion ifølge disse forfattere. Der er brug for andre former for intervention. Andre politiske værktøjer, der genopfinder demokratiet.

Denne artikels pointe er mindre bombastisk. Gennem en læsning af Mouffe med Laclau står Mouffes fokus på politisk praksis snarere end institutionel transformation tydeligere frem. Selvom Mouffe ikke er blind over for hverken institutioner eller sedimenteringen af politiske magtkampe, så har hun alligevel en tendens til at gøre det radikale demokrati til et diskursivt sprogspil. Det fremstår derfor ofte som om, at det radikale demokrati skal indføres i en institutionel verden, der uden videre lader sig transformere. Denne artikel handler ikke om, hvorvidt Mouffe har ret eller ej. Det ville være banalt blot at afvise hendes model, fordi hun tager et reformistisk-institutionelt perspektiv. Problemstillingen er snarere, at Mouffe for mig at se underkender de måder, hvorpå det eksisterende system fungerer ved at institutionalisere og neutralisere magt over tid. Idet Mouffe lægger reproduktionen af bestemte institutionelle og etiskpolitiske rammer til grund for hendes model, opretholder hun også delvist en række af de normative strukturer, hun søger at udfordre. Det liberale demokrati bliver på en gang det, der skal transformeres, men det bliver også midlet til denne transformation. Radikalt demokrati risikerer på denne måde at blive en affirmativ model snarere end et kritisk eller interventionistisk alternativ til eksisterende magtstrukturer. Den laclauianske pointe må netop være, at konstitutionen af de eksisterende politiske institutioner er udtryk for specifikke normative idealer, der er blevet neutraliserede, pakket sammen og glemt over tid. Det (neo)liberale demokrati er derfor fuldstændig indviklet og indgraveret i disse institutioner. For mig at se kan en læsning af Mouffe gennem Laclau være med til at synliggøre disse problemstillinger. På den måde kan vi begynde at videreføre og udvikle Mouffes model. Vi kan fortsætte med at radikalisere det radikale demokratis kritik af den neoliberale hegemoni og derigennem komme tættere på en ny politisk orden. 
Litteratur

Brown, W. (2015). Undoing the Demos: Neoliberalism's Stealth Revolution. Cambridge: Zone Books.

Critchley, S. og Marchart, O. (red.). (2004). Laclau: A Critical Reader. London: Routledge.

Dahlberg, L. (2014). Capitalism as a Discursive System? Interrogating discourse theory's contribution to critical political economy. Critical Discourse Studies, vol. 11(3), pp. 257-271.

Dahlberg, L. og Siapera, E. (red.) (2007). Radical Democracy and the Internet: Interrogating Theory and Practice. Basingstoke: Palgrave Macmillian.

Dardot, P. og Laval, C. (2013). The New Way Of The World: On Neoliberal Society. London: Verso.

Habermas, J. (2009 [1962]). Borgerlig offentlighed. København: Informations forlag.

Hardt, M. og Negri, A. (2004). Multitude: War and Democracy in the Age of Empire. New York: Penguin Press.

Howarth, D. (2000). Discourse. Buckingham: Open University Press.

Howarth, D., Norval, A. og Stavrakakis, Y. (red.). (2000). Discourse Theory and Political Analysis: Identities, Hegemonies and Social Change. Manchester: Manchester University Press.

Husted, E. (2015). Organiseringen af alternativ politisk deltagelse: Udkast til en typologi. Politik, vol. 18(2), pp. 13-23.

Kapoor, I. (2002). Deliberative Democracy or Agonistic Pluralism? The Relevance of the Habermas-Mouffe Debate for Third World Politics. Alternatives, vol. 27, pp. 459-487.

Karppinen, K., Moe, H. og Svensson, J. (2008). Habermas, Mouffe and political communication: A case for theoretical eclecticism. Javnost, vol. 15(3), pp. 5-22.

Khan, G. (2013). Critical republicanism: Jürgen Habermas and Chantal Mouffe. Contemporary Political Theory, vol. 12(4), pp. 318-337.

Laclau, E. (1990). New Reflections on the Revolution of Our Times. London: Verso.

Laclau, E. (1996). Emancipation(s). London: Verso.

Laclau, E. (2005). On Populist Reason. London: Verso.

Laclau, E. (2014). The Rhetorical Foundations Of Society. London: Verso.

Laclau, E. og Mouffe, C. (2014 [1985]) Hegemony and Socialist Strategy: Towards a Radical Democratic Politics. 2. udg. London: Verso.

Marchart, O. (2007). Post-Foundational Political Thought: Political Difference in Nancy, Lefort,. Badiou and Laclau. Edinburgh: Edinburgh University Press.

Mouffe, C. (1993). The Return of the Political. London: Verso.

Mouffe, C. (2005a [2000]). The Democratic Paradox. London: Verso.

Mouffe, C. (2005b). On the Political. London: Routledge.

Mouffe, C. (2013). Agonistics: Thinking the World Politically. London: Verso. 
Norval, A. (2007). Aversive Democracy: Inheritance and Originality in the Democratic Tradition. Cambridge: Cambridge University Press.

Schmitt, C. (2007 [1932]). The Concept of the Political. Udvidet udgave. Chicago: University of Chicago Press.

Schou, J. (2016). Ernesto Laclau and Critical Media Studies: Marxism, Capitalism, and Critique. tripleC, vol. 14(1), pp. 292-311.

Smith, A.M. (1998). Laclau and Mouffe: The Radical Democratic Imaginary. London: Routledge.

Tambakaki, P. (2010). Human Rights, Or Citizenship?. London: Birkbeck Law Press.

Torfing, J. (1999). New Theories of Discourse: Laclau, Mouffe and Žižek. Oxford: Blackwell Publishers.

Wenman, M. (2003). Laclau or Mouffe? Splitting the Difference. Philosophy \& Social Criticism, vol 29(5), pp. 581-606.

Žižek, S. (2000a). Da Capo senza Fine. In: J. Butler, E. Laclau og S. Žižek (red.). Contingency, Hegemony, Universality: Contemporary Dialogues on the Left. London: Verso.

Žižek, S. (2000b). Holding the Place. In: J. Butler, E. Laclau og S. Žižek (red.). Contingency, Hegemony, Universality: Contemporary Dialogues on the Left. London: Verso. 